\title{
Design and Construction of a Blood Flow Detector Probe for a Continuous Wave Bidireccional Doppler Ultrasound System
}

\author{
M. Fuentes*, A. Sotomayor*, F. García*, E. Moreno** y P. Acevedo* \\ *DISCA-IIMAS. Universidad Nacional A utónoma de M éxico y \\ **CEN US, Instituto de Cibernética M atemáticas y Física, La H abana, Cuba \\ E-mails: martin@uxdea4.iimas.unam.mx, soto@uxdea4.iimas.unam.mx, fabian@uxdea4.iimas.unam.mx, \\ moreno@ cidet.icmf.inf.cu y pedro@uxdea4.iimas.unam.mx1
}

(recibido: mayo de 2005; aceptado: noviembre de 2005)

\begin{abstract}
Thedesign and con struction of a blood flow detec tor probefor a Con tin u ous Wave (CW) Bidirectional D opp ler UI tra sound system is presented. This deviceis based on two pi ezo electricceram i cs work ing in con tin u ous modeandusing quadra turephasedemod u la tion for detectingthebloodflow Doppler signal. Theprobegen er ates thel (In phase) and Q (in Q uad ra ture) D opp ler signalsas au dio. Thesesignals are fed to the line in on the PC sound board for fur ther pro cess ing. $0 \mathrm{~s}$ cil la tor-transmitter and detector-demodulator cir cuits are in te grated into a $1.5 \times 9 \mathrm{~cm}$ printed cir cuit board (PCB). Pi ezo e lec tricce. ram ics are placed and con nected $1 \mathrm{~cm}$ apart the PCB, this achieves noise re duction and in creases the probesen si bil ity. Thecir cuit design al lows op er a tion at 4, 5, 8 and $10 \mathrm{M} \mathrm{Hz}$ de pend ing on the blood flow detection depth in ar ter ies or su per fi cial ves sels.
\end{abstract}

Keywords: UI tra sonic P robe, doppler sig nals, blood flow detector.

\section{Resumen}

Se presenta el diseño y construcción de una punta detectora de flujo sanguíneo para un sistema Ultrasónico Doppler Bidireccional de Onda Continua. Este dispositivo se basa en dos cerámicas piezoeléctricas operando de modo continuo y utiliza demodulación en cuadratura para la detección de la señal Doppler Ultrasónica del flujo sanguíneo. La punta detectora proporciona como salida las señales Doppler I (In phase) y $Q$ (in Quad ra ture) en rango audible. Estas señales se alimentan a la entradalinein de la tarjeta de sonido en una computadora personal PC para su procesamiento. Los circuitos oscilador-transmisor y detec tor-demodulador, han sido integrados en una tablilla de circuito impreso de dimensiones $1.5 \times 9 \mathrm{~cm}$. Las cerámicas piezoeléctricas están situadas y conectadas a $1 \mathrm{~cm}$ del circuito, logrando con una reducción del ruido y un incremento en la sensibilidad de la punta detectora. El diseño del circuito permite operar a 4,5,8 y $10 \mathrm{MHz}$, dependiendo de la profundidad de la detección del flujo sanguíneo en arterias 0 en vasos superficiales.

Descriptores: Punta ultrasónica, señales doppler, detección de flujo sanguíneo.

\section{Introduction}

In med ical ap plication, ul tra sound is exten sivelyused as a diagnos tic tool. There is a wide range of med i cal instruments which are used in this field from simple fetal phones to very sophisticated imaging sys tems. The main advantageof ultrasound when applied to diagnos tic is that it is non-invasive. In Cardi ology, the 
Design and Construc tion of a Blood Flow Detector Probe for a Contin uous Wave Bidireccional ...

ul tra sonic Dopp ler probe is a very use ful in stru ment to mon i torblood flow.

Blood flow velocity in arteries is periodic in time but its frequency spectrum varies during each cardiac cycle, therefore a blood flow Doppler signal is considered a cycle-stationary stochastic Gaussian signal and in short segments (2-20 ms) is considered a quasi-stationary signal. This signal is commonly analyzed using conventional methods such as the fast Fourier transform (Kay et al., 1981) and also using spectral estimation parametric methods to obtain a better resolution (Ruano et al., 1993).

In this paper the design and construction of a Continuous Wave (CW) blood flow detector probe is presented. This device detects the blood velocity, and flow disturbance by measuring the Doppler frequency shift of an ultrasound beam scattered from the blood flow, using quadrature phase demodulation. Processing the I and Q Doppler signals may provide information about the presence of stenosis and obstruction in arteries (Fish, 1991) (Goslinget al., 1975). Stenosis is a disease that affects blood flow velocity and pressure producing turbulence, due to this the velocity profile changes modifying the frequency spectrum of the signal, these changes determine the stenosis level.

This probe is compact, and includes I,Q quadrature blood flow signal as an output. Total circuit is integrated in $1.5 \times 9 \mathrm{~cm}$ printed circuit board. This device can operate within 4 to $10 \mathrm{MHz}$ range.

The main advantage of CW systems is that they measure blood flow high velocities with a high accuracy.

\section{Blood Flow Detector Probe}

The simplest blood flow Doppler detector probe is the one described by Sotomura (1960). At present this kind of probes are more compact and efficient, they are used as diagnostic tools in cardiovascular diseases more often.

The basic elements that build the probe are shown in figure 1 . This probe is a Continuos Wave (CW) device with coherent demodulation to obtain the I (In phase) and Q (in Quadrature) blood flow Doppler signals.

It is worth to mention that the blood flow Doppler signal is actually formed by two components which are the direct and inverse flow. Therefore it is necessary to have two signals in quadrature $\mathrm{I}_{\text {out }}$ and $\mathrm{Q}_{\text {out }}$ to be able to separate the flow direction, this is achieved using signal digital processing in the frequency domain (Evans et al., 2000).

The transmitter produces an ultrasonic signal that can be defined by the following expression:

where;

$$
T(t)=B \cos \left(\omega_{0} t\right)
$$

$\omega_{\mathrm{o}}=2 \pi \mathrm{f}_{\mathrm{o}}=$ angular frequency, and fo $=$ operation frequency of the ultrasonic transducer.

Considering that the ultrasonic signal received $S(t)$, it is formed by the carrier and the two resultant blood flow signals (forward and reverse), it is possible to express it as:

$$
S(t)=A_{0} \cos \left(\omega_{0} t+\phi_{0}\right)+A_{f} \cos \left(\omega_{0} t+\omega_{f} t+\phi_{f}\right)+
$$

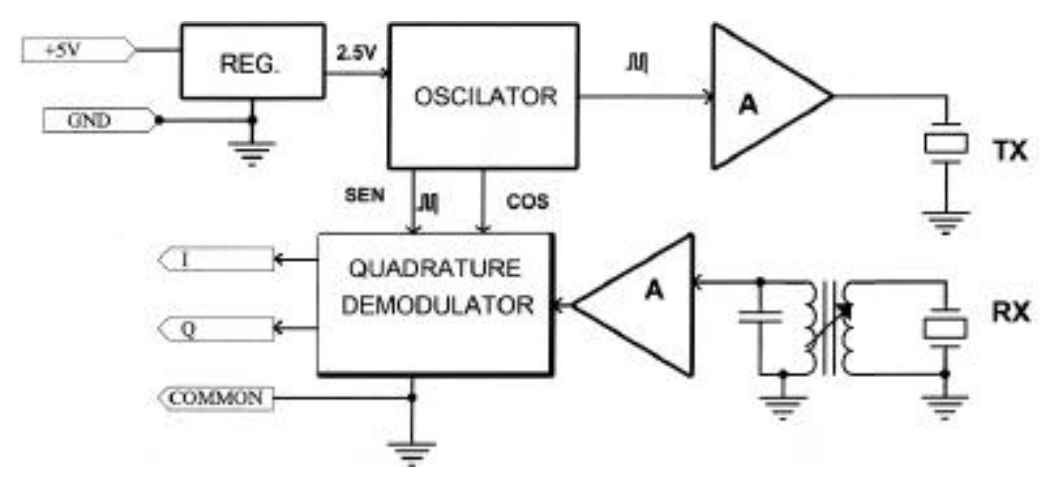

Figure 1. Sche matic diagram of the blood flow detector probe 
where $A, \omega y \phi$ are the amplitude, angular frequency and phase of each signal respectively. 0 , fyr are the carrier, the forward flow signal and the reverse flow signal respectively.

With the aim of preserving the real and imaginary components of the Doppler signal, the signal $S(t)$ is demodulated in quadrature.

This demodulation consists in multiplying by a signal of the same frequency from the transmitter $\operatorname{Cos}\left(\omega_{0} t\right)$ and its signal in quadrature Sen $\left(\omega_{0} t\right)$.

$$
\begin{gathered}
I(t)=S(t) \cos \left(\omega_{f} t\right) \\
I(t)=\frac{1}{2} A_{0}\left[\cos \left(\phi_{0}\right)+\cos \left(2 \omega_{0} t+\phi_{0}\right)\right]+ \\
\left.\frac{1}{2} A_{f}\left[\cos \left(\omega_{f} t+\phi_{f}\right)+\cos 2 \omega_{0} t+\omega_{f} t+\phi_{f}\right)\right]
\end{gathered}
$$

filtering high frequency and eliminating the d.c. components we obtain:

$$
I(t)^{\prime} \frac{1}{2} A_{f} \cos \left(\omega_{f} t+\phi_{f}\right)+\frac{1}{2} A_{r} \cos \left(\omega_{r} t-\phi_{r}\right)
$$

similarly the signal in quadrature is obtained,

$$
\begin{gathered}
Q(t)=S(t) \operatorname{sen}\left(\omega_{0} t\right) \\
Q(t)^{\prime}=-\frac{1}{2} A_{f} \operatorname{sen}\left(\omega_{f} t+\phi_{f}\right)+\frac{1}{2} A_{r} \operatorname{sen}\left(\omega_{f} t-\phi_{r}\right)
\end{gathered}
$$

then

$$
\begin{aligned}
& \text { I out }=\mid(t)^{\prime} \quad \text { is the In phase signal and } \\
& \text { Q out }=Q(t)^{\prime} \text { is the signal in Q uadrature. }
\end{aligned}
$$

\section{Description of the Elements of the Probe}

\section{Transducer}

The transducer used in the design of this probe as it is shown in figure 2, it was constructed using two piezoelectric discs PZT-5 with D form, one working as a transmitter and the other as a receiver. The frequency range depends on the application, for example for fetal phones $2 \mathrm{MHz}$, for blood flow detection in veins and arteries 4-5 $\mathrm{MHz}$ and for detection of blood flow in superficial veins 8-10 $\mathrm{MHz}$.

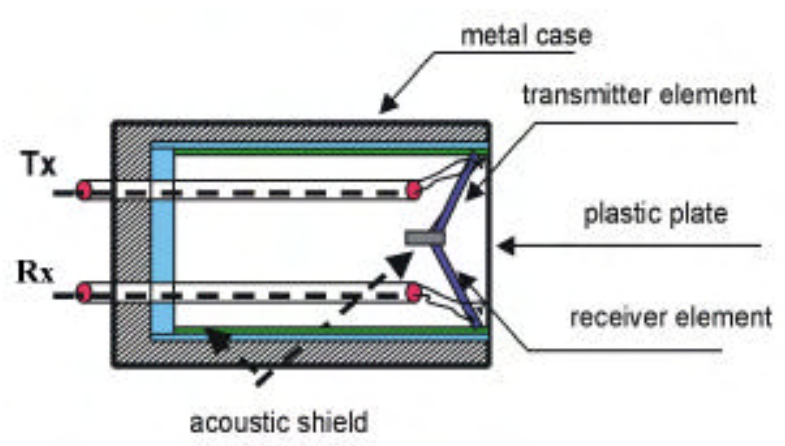

Figure 2. Ultra sonic Transducer

\section{O scilator-transmitter}

In this stage an ultrasonic continuous wave at the operation frequency is generated $(4,5,8$ or 10 $\mathrm{MHz}$ ). Also in this stage the signals in quadrature $\cos \left(\omega_{0} t\right)$ and $\sin \left(\omega_{0} t\right)$ at the same operation frequency of the transducer are generated. Figure 3 shows a schematic diagram of the circuit, it is worth to mention that when designing the transmitter it is convenient to take into account some characteristics such as power and matching impedance and these must fulfill the security levels recommended by the American Institute of Ultrasound in Medicine (AIUM) (Fish, 1991).

\section{Receiver - Demodulator in Quadrature}

The recuperated Doppler signal is very small, therefore it is necessary an RF amplification. Figure 4 shows the schematic diagram of this section. It consists of a RF transformer tuned to the operation frequency of the ultrasonic transducer, a FET transistor used as an RF amplifier in cascode configuration with two bipolar transistors which function is to mix the received signal with the signal in quadrature $\operatorname{Cos}\left(\omega_{0} t\right)$ and $\operatorname{Sen}\left(\omega_{0} t\right)$, advantage is taken of the $\mathrm{RC}$ components to limit the frequencies forming a low-pass filter cutting the high frequencies (Equation 4) leaving alone the blood flow Doppler signal. Two miniature trimmers are included in this section to balance lout and Q out, compensating small errors due to the variation of the electronic components. 
DOI: http://dx.doi.org/10.22201/fi.25940732e.2006.07n2.008

Design and Construc tion of a Blood Flow Detector Probe for a Contin uous Wave Bidireccional ...

Figure 3. Sche matic Diagram of the 0 scilator-transmitter. Compo nents marked with an * are dependant on the frequency oper a tion of the ultra sonictransducer

Figure 4. Sche matic Diagram of the Receiver-D emodulator in Q uad ra ture. Compo nents marked with an *, must be tunned up at the ultra sonictrans ducer's frequency 
If we consider that the human blood flow velocity profile has a range of $20-700 \mathrm{~mm} / \mathrm{s}$, and the ultrasonic velocity in tissue is about $1540-1600$ $\mathrm{m} / \mathrm{s}$ (Fish, 1991) (Atkinson, 1975) (Vaitkus et al., 1988), using ultrasonic transducers within 2-10 $\mathrm{MHz}$ we are able to estimate the range of the recovered blood flow Doppler signal.

The Doppler signal is given by:

$$
\mathrm{Fd}=(2 \mathrm{v} / \mathrm{c}) \mathrm{fo}_{0}
$$

So the blood flow Doppler signal lies within $200-10,000 \mathrm{~Hz}$, that is the audible range and it is relatively easy to divide the high frequencies from the signal of the detector.

\section{Experiments and Results}

To verify the performance of the probe (Figure 5) the I and Q outputs were connected to an amplifier and filter of two channels. The filters used were fifth order band-pass filters with a cut frequency of 300 and $8000 \mathrm{~Hz}$ and an amplification of $40-50 \mathrm{~dB}$ per channel.
These filters and the probe were designed and constructed as an integral section of a bi-directional blood flow Doppler system at DISCAIIMAS-UNAM laboratory.

Using MATLAB 6.1 tools, I, Q blood flow signals coming from the probe were acquired using a PC Pentium III audio board, these signals were stored as WAV files. Figure 6 shows these signals.

To verify the frequency spectrum of the acquired I, Q signals, an specific software was developed to display the spectogram of the blood flow signal as shown in figure 7 .

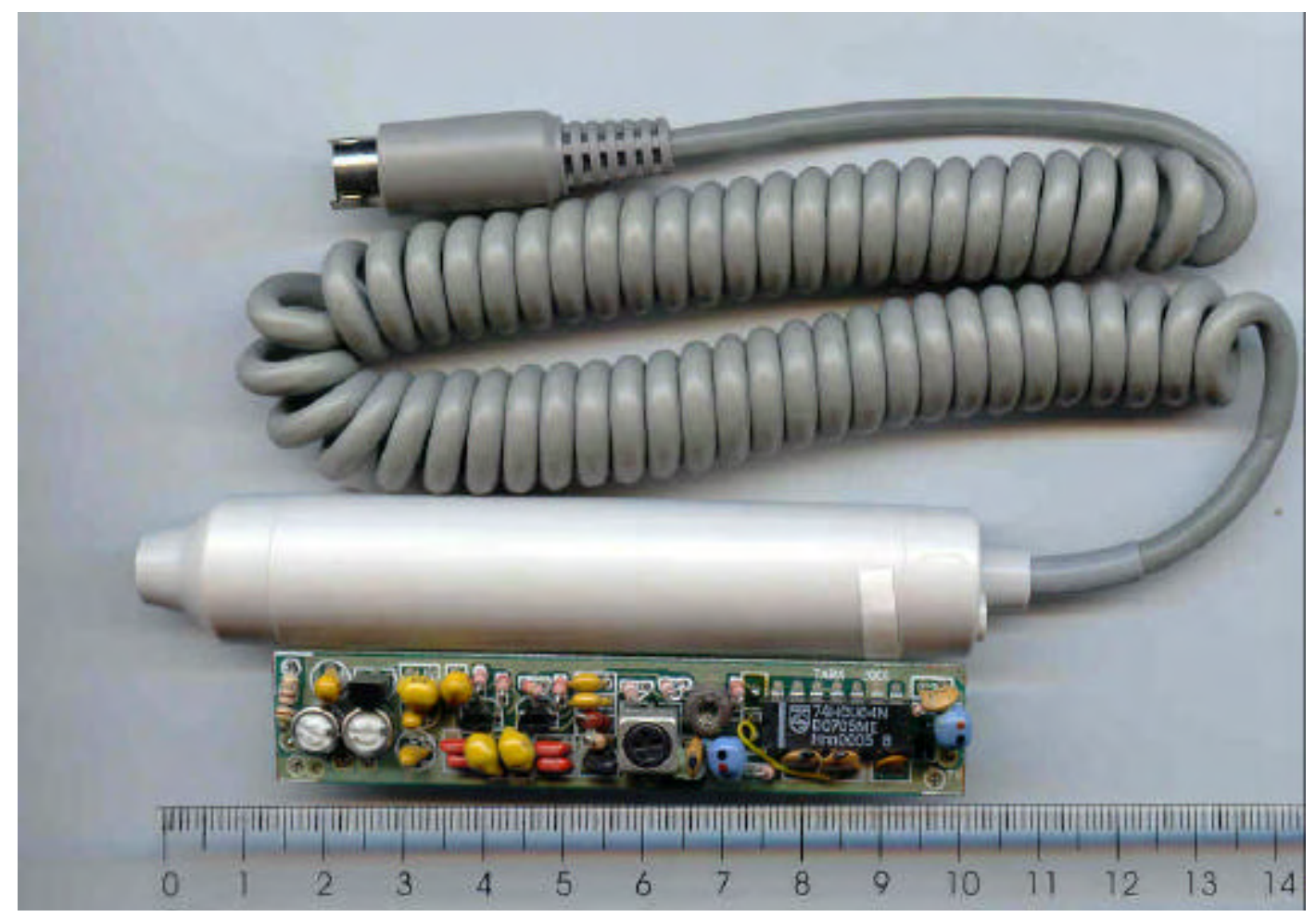

Figure 5. Detector probe with

printed circuit board, ultra sonic trans ducer (probe), PVC container and connector cable (scale is in $\mathrm{cm}$ ) 
Design and Construc tion of a Blood Flow Detector Probe for a Contin uous Wave Bidireccional ...
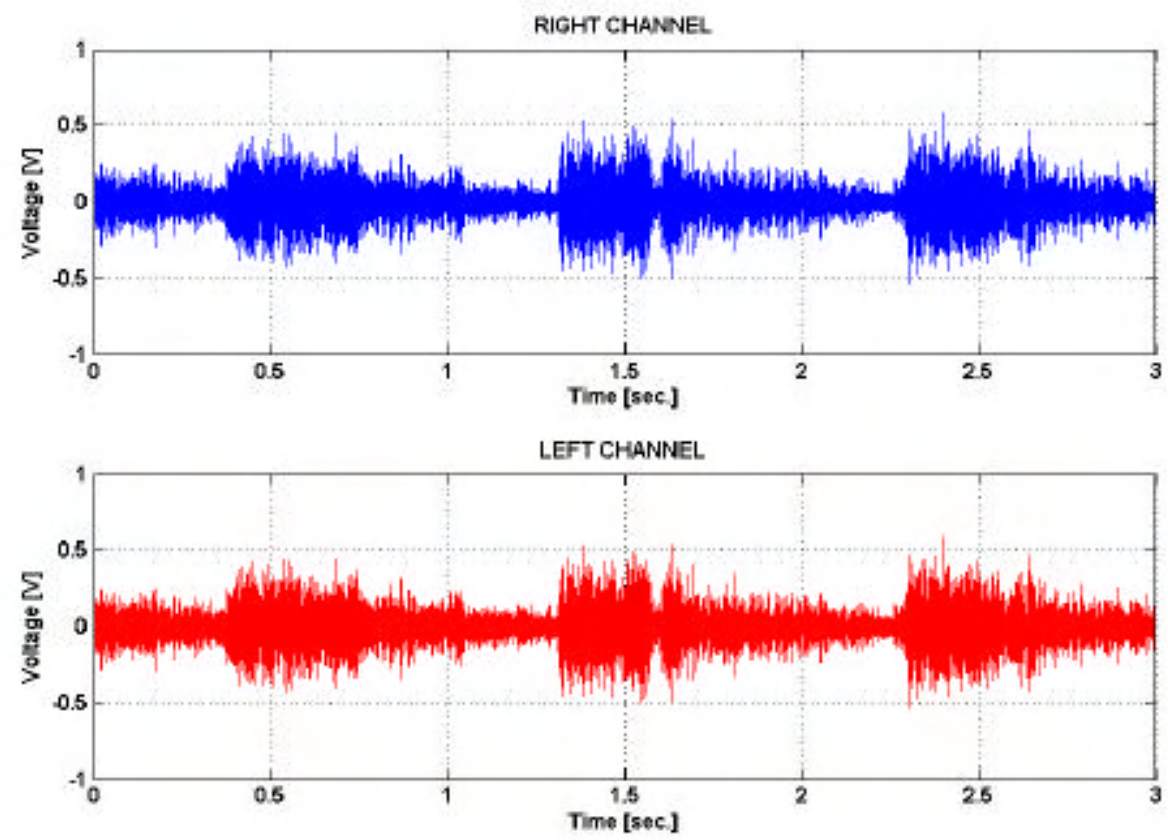

Figure 6. Segments of a blood flow ultra sonic Doppler signal (I and Q), from a carotid artery acquired using $4 \mathrm{M} \mathrm{hz}$ probe and a PC audio board with a $22 \mathrm{Khz}$ sample frequency

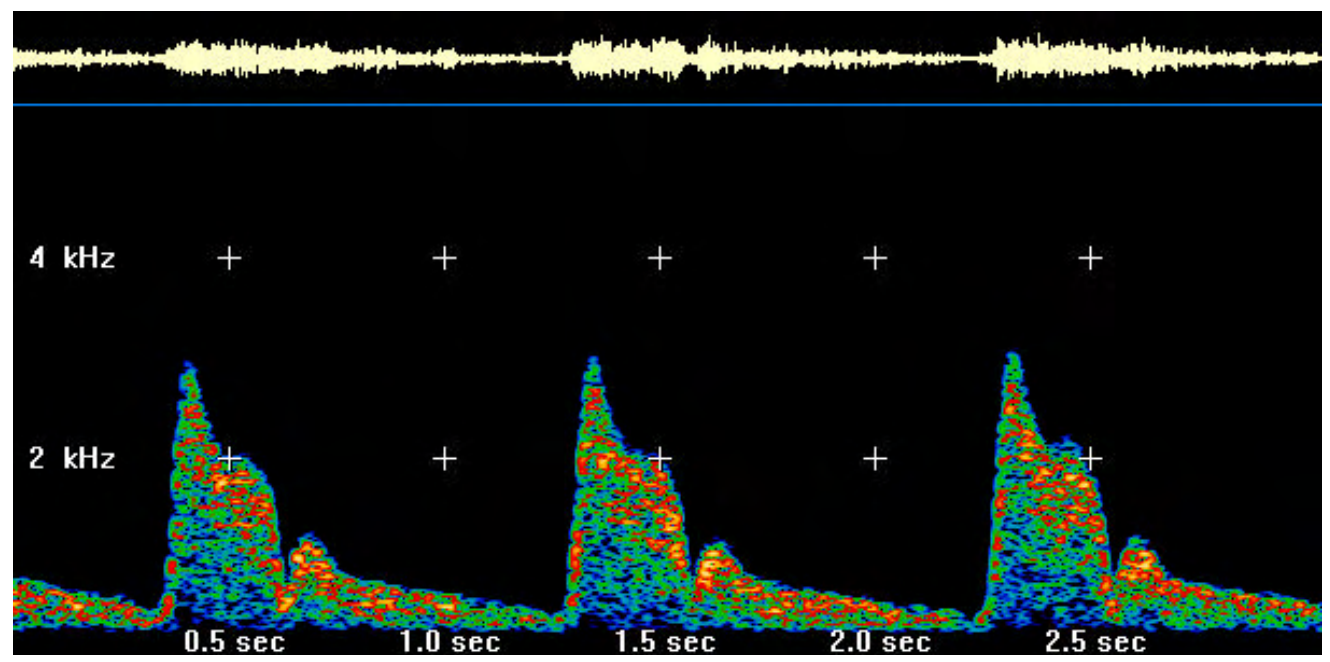

Figure 7. Spectogram of one of the signals in figure 6. A method based on the Short Time Fourier Trans form (STFT), with a 512 points sampling window was used

\section{Conclusions}

The blood flow Doppler detector probe has a good performance, having the transmitter and receiver at a short distance from the piezoelectric discs and also having a good shield gives to the probe good sensibility and low noise. The design of the circuit allows the probe to operate within a range of 4 to $10 \mathrm{MHz}$ depending on the depth of the blood flow detection in veins and superficial blood vessels. Validation of the performance of the probe has been made acquiring real signals associated to the blood flow in arteries, and also processing and displaying these signals as spectograms. Comparison of these spectograms with spectograms produced with commercial equipment has shown the good performance of the detector probe. 


\section{Acknowledgements}

The authors acknowledge the support of DGAPAUNAM (PAPIIT-IN120103) (PAPIIT-IN111303).

\section{References}

Atkinson P. (1975). A Fundamental Inter preta tion of UItrasonic Doppler Velocimeter. Ultrasound in Med. Biol., 2, pp. 107-111.

Evans D.H and Mc Dicken W.N. (2000). Doppler Ultrasound, Physics, Instrumentation and Signal Processing. John Wiley \& Sons, LTD. Second Edition, pp. 101-104.

Fish P.J. (1991). N on-Stationary Broadening in Pulsed Doppler Spectrum M easurements. Ultrasound in Medi cine \& Biology, Vol. 17, pp. 147-155.
Gosling R.G. and King D.H. (1975). Ultrasonic Angiography in Arteries and Veins. (Eds. A.W. Hascus and L. Adamson). Edin burgh, pp. 61-98.

Kay S.M. and Marple S.L. (1981). Spectral Analysis a Modern Perspective. Proc. of the IEEE, 69, pp. 1380-1419.

Ruano M.G., García-Nocetti D.F., Fish P.J. and Fleming P.J. (1993). Alternative Parallel Implementations of an AR-M odified Covariance Spectral Estimator for Diagnostic Ultrasonic Blood Flow Studies. Parallel Computing, 19, pp. 463 - 476. Sotomura, S. (1960). UItra sonic D oppler M ethod for the Inspection of Cardiac Funtions. Acoust. Soc. Am., Vol. 29, pp. 1181-1185.

Vaitkus P. and Cobbold R. (1988). A Comparative Study and A ssess ment of D oppler U Itra sound Spectral Esti ma tion Tech niques, Part 1. Ultra so und in Medi cine \& Biology, 14, pp. 661-672.

\section{Semblanza de los autores}

M artín Fuentes. Es ingeniero mecánico electricista (área de electrónica), egresado de la Facultad de Ingeniería de la UNAM. Labora en el IIMAS desde 1983. Ha colaborado en diferentes proyectos institucionales dentro y fuera de la UNAM, tales como: Instituto de Ciencias del Mar y Limnología, Instituto de Biología, Instituto de Geofísica, Museo Universum, Instituto Mexicano del Petróleo y el Departamento de Ultrasónica del ICIMAF-CUBA. Ha realizado estan cias de trabajo en España, Cuba y Brasil. Sus áreas de especialidad son la instrumentación sismológica, oceanografía, meteorología y monitoreo atmosférico, así como ultrasónica médica e indus trial.

Alejandro Sotomayor. Es licenciado en ingeniería electrónica y maestro en ciencias por el Instituto Supe rior Politécnico de la Habana, Cuba, desde 1992. Ingresó al Instituto de Cibernética Matemática y Física de Cuba, en el Centro de Ultrasónica en 1994. Para el año de 2001, ingresó al Instituto de Investigaciones en Matemáticas Aplicadas y en Sistemas, UNAM.Las líneas de investigación que desarrolla actualmente son el diseño de transductores, instrumentación ultrasónica y procesamiento de señales para medicina y Pruebas No Destructivas (PND).

Fabián García. Egresó en 1984 de la Facultad de Ingeniería de la UNAM con mención honorífica. Recibió los grados de maestro y doctor en el área de sistemas de cómputo por la Universidad de Gales, Bangor, Reino Unido, en 1988 y 1991 , respectivamente. Recibió el Premio Nacional de Ingeniería “Emilio Rosenblueth 1996", otorgado por la Academia Nacional de Ingeniería, así como el Premio "Ciencia e Ingeniería de la Computación" en el año 2000. Se especializa principalmente en cómputo de alto desempeño, procesamiento de señales e imágenes, imagenología ultrasónica, tomografía de procesos, computación móvil y redes inalámbricas. Actualmente es investigador titular "B" del IIMAS.

Eduardo M oreno. Es físico por la Facultad de Ciencias de la Universidad de la Habana, Cuba. Desde 1980, labora en el Centro de UItrasónica (CENUS-ICIMAF), Cuba, con categoría de investigador. En 1994, obtuvo su doctorado en ciencias físicas por la Academia de Ciencias de Cuba, y para mayo de 2000 a mayo de 2002, se desempeñó como investigador del IIMAS-UNAM, así como profesor en el Posgrado en Ciencia e Ingeniería de la Computación de la UNAM. Actualmente es jefe de proyecto en el CENUS-ICIMAF. Las áreas de investigación que estudia son el procesamiento de señales e imágenes, así como imagenología ultrasónica.

Pedro A cevedo Es egresado de la Facultad de Ingeniería de la UNAM en 1984. Recibió los grados de maestro (Instrumentación) y doctor (Ultrasonido) por la Universidad de Gales, Bangor, Reino Unido en 1987 y 1992, respectivamente. Actualmente es investigador titular "A" y jefe del Departamento de Ingeniería de Sistemas Computacionales y Automatización del IIMAS. Asimismo, es profesor de asignatura en la Facultad de Ingeniería de la UNAM. Sus líneas de investigación son el procesamiento de señales e imágenes, imagenología ultrasónica, diseño, modelado, construcción y caracterización de transductores ultrasónicos. También pertenece al Sistema Nacional de Investigadores del CONACYT. 